\title{
Impressions of Urban Forestry in China
}

\author{
D. F. W. Pollard
}

\author{
Canadian Forestry Service \\ Petawawa Forest Experiment Station \\ Chalk River, Ontario
}

\begin{abstract}
"There is another regulation adopted by the grand Khan, equally ornamental and useful. At both sides of the public roads, he causes trees to be planted, of a kind that become large and tall, and being only two paces asunder, they serve (besides the advantage of their shade in summer) to point out the road (when the ground is covered with snow); which is of great assistance and affords much comfort to travellers. This is done all along the high roads, where the nature of the soil admits of plantation; ..."
\end{abstract}

Marco Polo

What has urban forestry to do with elevating $800,000,000$ people from poverty and oppression? Whatever the answer, foresters visiting China quickly realise that urban forestry has enjoyed high priority during the past three decades of social reconstruction. China's record of street planting stretches back over millennia, to the Chou and Ch'in dynasties, and obviously impressed Marco Polo in the thirteenth century. But it is the magnitude of recent endeavours that impresses modern travellers. This article is an account of some of these endeavours; hopefully an answer to the above question will become apparent.

The opportunity to visit the Peoples Republic of China came in 1975, when the Canadian Forestry Service sent a delegation to further scientific exchange between the two countries. The delegation consisted of two people, Ross Macdonald, a program manager and specialist in biological control from the Pacific Forest Research Centre, and myself, a tree physiologist at Petawawa Forest Experiment Station. Our purpose was to examine China's progress in biological control of forest pests, forest genetics, and tree physiology. We also intended to examine ways of exchanging insect parasites, predators, pathogens and tree seed. The opportunity to see something of China's recent achivements in urban forestry was to be a bonus.

The itinerary provided by our hosts, the Chinese Academy of Sciences, took us north from Peking to the Manchurian cities of Harbin, Changchun and Shenyang, then south to Nanking, Shanghai, Hangchow, and finally into the subtropical city of Kwangchow. We were accompanied by an interpreter (whose command of English was first-rate and who was never stumped for a species name) and a guide; both proved to be excellent companions.

Our three-week tour began in late November with four days in Peking; we were immediately struck by the extent of roadside planting. The thirty kilometre drive from the airport was through one long avenue and practically every street we visited in the city was lined with trees. It was a pattern to be repeated wherever we went.

More by accident than design, much of our travelling was by train. Chinese trains are fast, reliable and punctual to the minute. We spent three nights on trains and came to know them fairly well. Our four-berth cabin was comfortable and, like hotel rooms, always furnished with fresh fruit, cigarettes, tea and the inevitable huge vacuum flask filled with hot water.

The advantage of trains over planes, of course, lies in the opportunity to see countryside at ground level. We were particularly impressed by the trackside plantings: three or four rows deep, plantations extended almost without break for hundreds of kilometres. There was a striking difference between city street and rural road and railway plantings. Whereas city trees tended to be species valued for their shade and aesthetic characteristics, rural species had been chosen for timber value. Thus Korean pine (Pinus koreaiensis) and Scots pine ( $P$. sylvestris var. mongolica) supplement the willows and poplars along country roads and railways. Usually a different species could be seen in each row parallel to the route.

The material use of urban trees goes beyond timber production. So-called "economic" species are planted for crops such as oil, nuts and fruit. In more rural areas we observed that dead limbs and litter are almost instantly recovered - to the detriment of soil condition sometimes - by local peasants for fuel. According to a "Time" magazine report, street trees in Peking provided materials for temporary shelters following the catastrophic earthquakes of 1976.

Apart from trees in temple gardens, palaces and other historic sites, it is quite evident that urban forests of China today are very young - certainly less than thirty years. It is also evident that planting was undertaken on a massive scale in the decade following Liberation in 1949. Explanation can be found in the wars and subsequent political upheavals that preceded Liberation. City trees were completely removed for fuel; at the same time, great forests of the hinterlands had been decimated during Japanese occupation, partly for fuel and timber, and partly to reduce cover for guerilla forces. By 1949, the eastern part of the country was practically treeless. Mao Tse-Tung's challenge "make the countryside a garden" was answered with a massive effort of reforestation, urban and rural, that has continued to this day. While street plantings are the most conspicuous 
achievements of urban forestry in China, the nation-wide "greening drive" has extended into every crevice of the urban environment. Residential areas, hospitals, universities, public buildings and factories all show signs of intensive planting. In Shenyang we were introduced to a cooperative venture between the Shenyang Institute of Forestry and Pedology and a local chemical factory manufacturing soda lime and related products. With assistance from the municipality, over 2000 trees had been planted on the factory site since 1972. Planting was based on results of laboratory experiments with fumigation chambers, on observations of vegetation in polluted sites, and on field trials in the factory itself. From results thus obtained, a number of species had been classified according to their ability to survive complex aerial pollutants; some examples are listed in Table 1. Our host at the factory waxed enthusiastically about the virtues of resistant species such as Persica (= Prunus davidiana, whose blossoms delight but whose yellowing foliage warns workers of excessive pollution.

The task of genetic improvement of trees is beset with difficulties in China, not least of which is the dearth of native material in eastern parts of the country. Depletion of the gene pool took place on a devastating scale during and after the last

Table 1

Rating of resistance to airborne pollutants (compiled by Shenyang Institute of Forestry and Pedology)

Group 1 Strong resistance (strong tolerance or strong tendency to recover)

\section{Ginkgo biloba}

Ailanthus altissima

Gleditschia japonica

Makia amurensis

Persica (Prunus) davidiana

Populus canadensis

Robinia pseudoacacia

Salix matsudana

Sophora japonica

Tamarix chinensis

Ulmus pumila

Zizyphus jujuba

Group 2 Medium resistance (symptoms of serious injury, e.g., deformed crowns]

Abies holophylla

Pinus densiflora

Pinus sylvestris var. mongolica

Acer mono

Acer ginnala

Castanea mollissima

Catalpa ovata

Celtis bungeana

Paulownia fortunei

Phellodendron amurense

Tilia mandshurica

Group 3 Weak resistance (buds wither; death)

Larix spp.

Pinus koraiensis

Pinus tabulaeformis

Juglans mandshurica

Juglans regia

Malus baccata

Malus pumila war. Trees hardy to the climate of northeastern provinces are sought in western regions, and are augmented by hybrids. We learned how walnut and chestnut (two "economic" species) had been selected and improved for frost hardiness in Heilungkiang province; that chestnut collected close to the Great Wall near Peking had proved hardy to $-27^{\circ} \mathrm{C}$; and that recent crosses between Juglans mandshurica $x$ J. regia had shown particular promise when the female parent was $\mathrm{J}$. mandshurica (the hardier of the two).

Municipal achievements in urban forestry are well illustrated by the "greening program" of Nanking, the former capital city. The example will also convey how achievements are portrayed not without foundation - for political propaganda. The following paired data represent changes that have taken place since Liberation of 1949: "scenic" forests have increased from 1762 ha to 3468 ha;

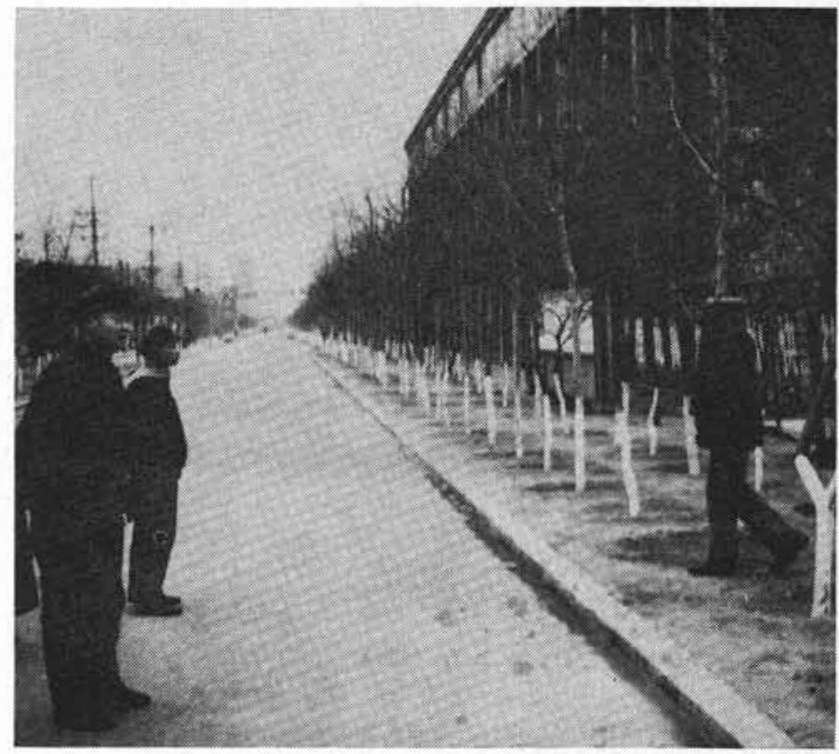

each and poplar saplings line one of the main roads through a Shenyang chemical factory. The factory conducts trials for pollution resistance in coopération with a local university.

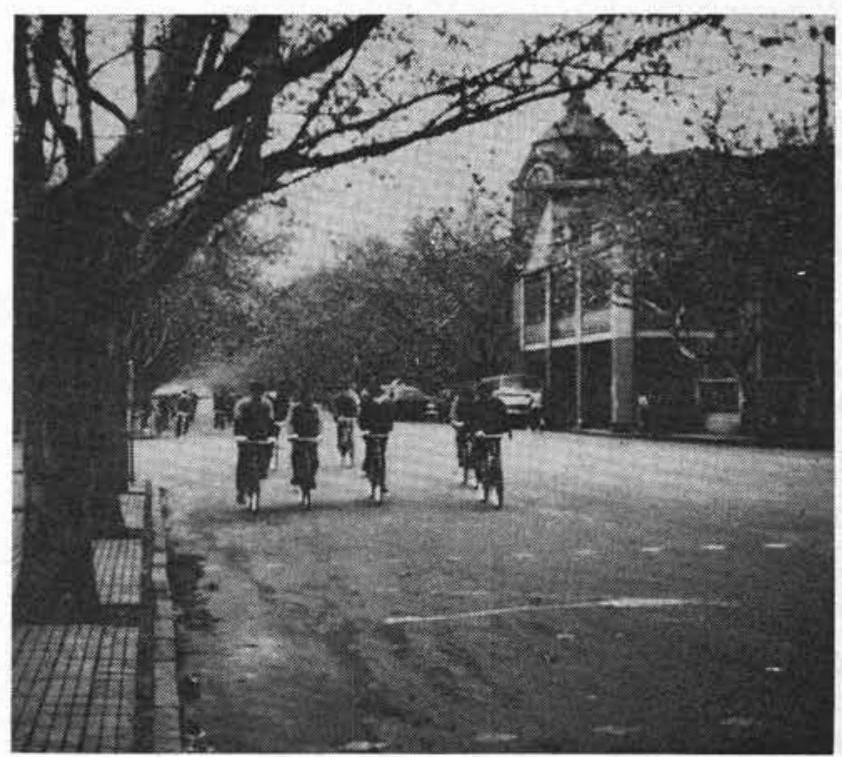

Well-manicured boulevard provides pleasant cycle route for workers in Hangchou. 


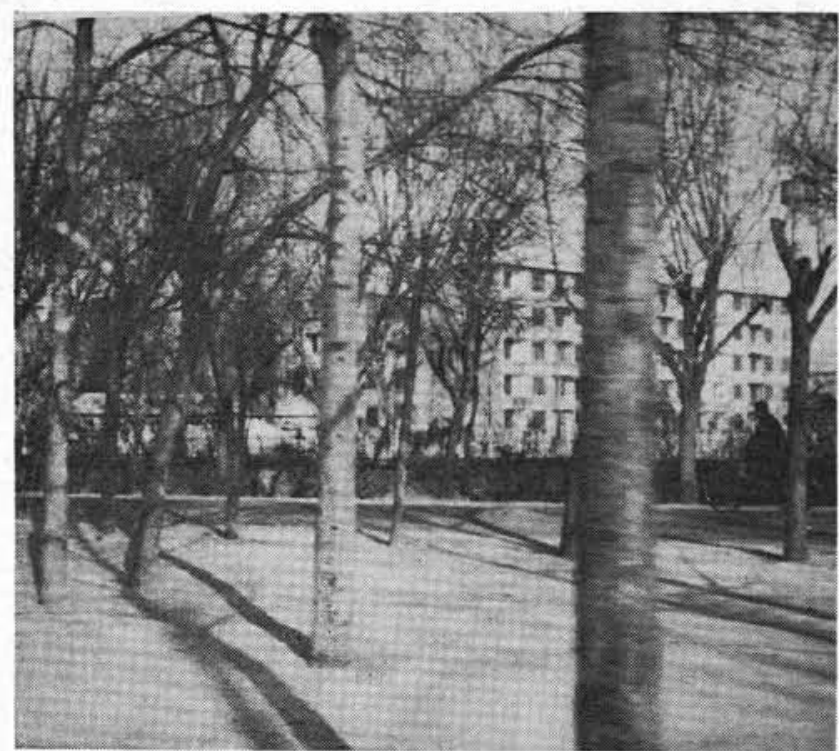

Typical broad verge separating road from cycle path in Peking; soil around trees is compacted by frequent trampling.

there are now 18 parks compared with 5 formerly; planting around buildings, once restricted to residences of high officials, has increased from 104 ha to over 2000 ha, and includes factories and worker residential areas; street trees have mushroomed from 2750 to over 200,000 . The figures were borne out by our own observations. Particularly impressive were the numerous boulevards of Platanus acerifolia, whose manicured crowns formed a virtual canopy across the divided city streets. The outer lanes carried cyclist traffic while the inner corridor was used by trolley buses, trucks, cars and more cyclists. We were told that cyclists preferred the shaded boulevards to shorter unshaded routes. It was also pointed out that stores no longer used awnings over their windows. Nanking is very hot in summer and there are bound to be microclimatic benefits from the planting completed to date.

We were assured that the ostensible, tangible benefits from the tree planting serve as encouragement to the people at large to participate in such schemes. Throughout society there is an extensive and pervasive system of technological transfer through which expertise is rapidly passed from specialists to the workers. Indeed, a reverse flow of ideas may develop, where workers will advise researchers of shortcomings or necessary changes in new schemes, or will even reject research findings and conduct their own investigations. Just how effective or disruptive this would be is difficult for the visiting observer to assess, but there can be no doubt that continuing liaison between "specialists" and "the masses" is a high priority in the new China. Arboriculture provides a vivid example. Urban trees are maintained by workers, not by "tree experts", and urban forestry is taught in schools as a component of labour education and the national health movement.

Tree nurseries abound in China. Our tour took us to two, one provincial and one associated with a university. Neither revealed advanced production techniques - cold frames and conventional greenhouses seemed to be the order of the day. But what nurseries may lack in sophistication they make up for in numbers. Every municipality operates its own nurseries for horticultural and forestry purposes. Even the chemical factory in Shenyang ran its own greenhouse propagation unit. And we saw small nurseries by the dozen in communes as we travelled about the country.

Our itinerary included several universities, where we learned of education and research in forestry and related sciences. Arboriculture and horticulture were not on our list, but it was clear from the response to our own lectures on Canadian forestry that there was much interest in our cultural practices. Following his visit to China Richardson (1966) noted the survival of P'an tsai, the classical Chinese arboriculture of landscaping in miniature, but commented on how this and other forms of ornamental tree culture were giving way to more practical needs of city parks and streets.

It may seem odd that botanical gardens should have come under scrutiny with the new social order. But this illustrates the approach to progess in modern China. Everything must be relevant it seems, and to be relevant it must be functional and productive. The role of botanical gardens has been uncertain for some time and important collections such as the Kwangtung Botanical Garden in Kwangchow (Canton) have been closed to visitors in recent years. We were fortunate to visit the latter and were impressed by the collection of ferns and sub-tropical and warm-temperate herbs, both of which have a vital place in communal medical practice. The garden serves as a test site for exotics with productive potential, as a reference collection, and, perhaps most important, as a centre for education. Yet seated in the modern but decidedly oriental summer house overlooking a small lake and its attendant plantations of Taxodium and Cyptomeria, we were reassured to find that the Chinese had not completely forsaken their gift for creative landscaping.

China has a population forty times that of Canada, in an area slightly smaller than this country. Much of the land to the north and west is desert or mountainous, so that both population and agriculture are concentrated in the east. And concentrated they are too. Everywhere we travelled we saw intense utilization of the land. We found the extent of human intervention disturbing at times. There was virtually no wildlife habitat designed into this man-made environment. Paradoxically, we saw a greater variety of birds around the preserved grounds of the Ming tombs than in forests and agricultural lands we passed through. The countryside has been devastated but its productive capacity has been restored and improved. With so many new plantations, in forests, on agricultural land, and in cities, China can probably also look forward to some restoration of wildlife capacity. 
It seemed to us that trees symbolize China's progress. They trace a continuum of endeavour, from the "Great Green Wall" planted in the path of the encroaching Gobi desert to the avenues in northern industrial cities like Harbin and Shenyang. Urban trees help Chinese people to meet basic needs of shelter, warmth, food, health, even living space, as well as providing them with more comfortable and pleasant environments. As far as we could see, everyone in China benefits from urban forestry - can we claim the same for Canada? And to think that we were asked after one of our lectures, "What is this urban forestry?"

\section{Reference}

Richardson, S.D. 1966. Forestry in communist China. John Hopkins Press, Baltimore, Maryland.

\section{Editor's Note}

The following résumés were not available in time for the August issue in which the papers appeared. They are therefore reproduced here for the information of readers.

\section{Trends and Prospects in Ontario's Poplar Plantation Management}

\section{Zsuffa, H. W. Anderson and P. Jaciw}

Ontario Ministry of Natural Resources

Forest Research Branch

Maple, Ontario

\section{Résumé}

Les objectifs et les systèmes d'aménagement des plantations de peupliers-hybrides, quelques-uns des problèmes, et les résultats des travaux antérieurs sont résumés dans cet article.

Les plantations de peupliers à courte révolution sont composées d'arbres de dimensions traditionnelles, régulièrement espacés et aménagés intensivement en monoculture. Les problèmes sylvicoles sont associés à la sélection des clônes, au choix des stations de même qu'au traitement, à l'espacement et au type de matériel à planter. Les accroissements annuels moyens des meilleurs variétés ont atteint $29 \mathrm{~m}^{3} /$ ha ( $400 \mathrm{pi}$. cu./acre) à l'âge de 12 ans.

Les plantations de peupliers de "type forestier" sont étalies dans des aires de forêt exploitée. Celles-là sont aménagés moins intensivement.

Le peuplier à croissance rapide et les conifères et feuillus tolérants à l'ombre qui lui sont associés forment des plantations mélangées (polyculture du peuplier) sur des stations très variables. Les influences bénéfiques sont apparentes dans la qualité des tiges et la phénologie des arbres associés. Des effets de stimulation de croissance, d'utilisation accrue de la station et de résistance aux maladies sont espérés dans ces conditions.

Dans un système de mini-révolution, des rendements à sec moyens de $8 \mathrm{t} / \mathrm{ha} / \mathrm{a}$ ( 3.5 tonnes/acre/année) ou plus sont obtenus dans des plantations âgées d'un à trois ans, aménagées intensivement et peu espacées. Des essais de transformation en pâte donnent des qualités satisfaisantes. En plus, plusieurs autres usages, des substituts pétrochimiques à la nourriture, présentent un potentiel. Les problèmes d'aménagement sous étude sont: la sélection de clônes, le traitement des stations, l'espacement et la mécanisation.

\section{Hardwoods Within the Complete Forest Concept}

\author{
Harold E. Young \\ Complete Tree Institute \\ School of Forest Resources \\ University of Maine \\ Orono, Maine 04473 USA
}

\section{Résumé}

Le concept de l'arbre entier, I'investigation biologique et technologique de l'arbre entier du bout des racines au bout des feuilles inclusivement, a été beaucoup plus incorporé dans I'aménagement et l'utilisation des feuillus que des résineux au cours des dix dernières années. L'exploitation mécanisée centrée sur les déchiqueteuses mobiles a augmenté la production à l'hectare dans les peuplements feuillus d'environ $100 \%$ en utilisant les cimes aussi bien que les petits arbres de toutes les espèces feuillues non utilisées antérieurement. Tous les usages traditionnels des feuillus s'étendent pour rencontrer la demande et simultanément il y a un usage accrû pour l'énergie, la nourriture à bestiaux et les produits chimiques comme le xylitol. Avec la pénurie reconnue de ressources fossiles, les chimistes et les ingénieurs examinent critiquement les forêts, notre ressource renouvelable, indiquant qu'un usage accrû des feuillus est certain.

Des révolutions courtes de 3-10 ans, impliquant des milliers de tiges à l'hectare, souvent comme résultat de traitements de taillis, sont étudiées pour plusieurs espèces feuillues. Ceci résultera en un aménagement forestier intensif semblable à l'agriculture, excepté que la production de fibres plutôt que de fruits sera accentuée. Les progrès dans I'aménagement à révolution courte des feuillus resteront toujours en arrière de l'utilisation des feuillus car les durées de développement ne sont pas les mêmes. Donc ceux impliqués dans l'aménagement devront s'appuyer sur la prévoyance comme moyen de garantir des forêts viables et productives à mesure que la connaissance augmentera.

\section{Energy from Forest Biomass}

\section{Marc H. Schneider}

Department of Forest Resources

University of New Brunswick

Fredericton, N.B.

\section{Résumé}

La biomasse forestière peut être transformée en énergie par la combustion directe ou par la conversion en carburant gazeux ou liquide avant le brûlage. Un tel carburant peut avoir une utilisation domestique, dans le transport, les industries et les services publics. Ce document passe en revue quelques caractéristiques de base du carburant provenant du bois, l'état actuel de la technologie du carburant issu de la biomasse forestière et les résultats de quelques études récentes sur la possibilité de transformer le bois en combustible.

\section{Opportunities In Hardwood Utilization}

\section{B. Flann}

Résumé

Eastern Forest Products Laboratory, Ottawa, Ontario.

On passe en revue l'ensemble des produits généralement manufacturés avec les feuillus en donnant un indice sur la qualité des bois requise. On traite également de l'état de détérioration de l'approvisionnement en bois dur et de deux façons d'envisager le problème: amélioration de l'allocation en bois rond et plus grande efficacité dans les techniques de transformation. La dernière méthode est discutée avec quelques détails. 